\title{
Autocrine interferon- $\gamma$ may affect malignant behavior and sensitivity to tamoxifen of MCF-7 via estrogen receptor $\beta$ subtype
}

\author{
XIU LONG NIU ${ }^{1,2}$, YUE WANG ${ }^{3}$, ZHI YAO $^{1}$, HONGJIE DUAN $^{1}$, ZHIJUN LI $^{1}$, \\ WENXING LIU ${ }^{1}$, HONGJIAN ZHANG ${ }^{1}$ and WEI MIN DENG ${ }^{1}$
}

\begin{abstract}
${ }^{1}$ Department of Immunology of Tianjin Medical University, Tianjin Key Laboratory of Cellular and Molecular Immunology, Key Laboratory of Diseases and Microenvironment of Ministry of Education of China; ${ }^{2}$ Department of Infectious Diseases, Hospital Affiliated to Logistics College of Chinese People's Armed Police Forces; ${ }^{3}$ Department of Immunology,

Logistics College of Chinese People's Armed Police Forces, Heping, Tianjin, P.R. China
\end{abstract}

Received June 12,2015; Accepted July 23, 2015

DOI: 10.3892/or.2015.4294

\begin{abstract}
Mitogenic actions of estrogens are mediated by two distinct estrogen receptors (ERs), which are critical in the progression and therapeutic response of breast cancer. ER expression is a dynamic phenomenon that is regulated by numerous factors, including cytokines, in the tumor microenvironment. Recently, studies have shown that autocrine production of IL-4 promotes cancer cell growth and there is negative correlation between tumor IL-4 and hormone receptor levels, suggesting that there is crosstalk between cytokine receptors and ER. Thus, we evaluated for interaction between the two ERs and the cytokines IL-4 and IFN- $\gamma$, and if this interaction modulates malignant behavior. We identified that ER $\beta$ exerts protective activity in the progression of breast cancer cell line MCF-7, which co-expresses $\mathrm{ER} \alpha$ and ER $\beta$. IFN- $\gamma$ and IL-4 have the opposite effects on malignant biological behavior. Furthermore, we found positive correlation between IFN- $\gamma$ and ER $\beta$ expression in MCF-7. We also determined that autocrine IFN- $\gamma$ in MCF-7 increases mRNA expression of ER $\beta$ resulting in enhanced sensitivity to tamoxifen (TAM). These results indicate that ER $\beta$ and autocrine IFN $-\gamma$ represent two putative targets for breast cancer therapy.
\end{abstract}

\section{Introduction}

Breast cancer is the second most frequent cancer-related death worldwide (1). In China, it is predicted that breast cancer incidence will increase to $85 / 100,000$ women by 2021 (2). Estrogen is a key hormone in breast cancer development. Estrogen exerts its biological activity, including enhancing cell

Correspondence to: Dr Wei Min Deng, Department of Immunology, Tianjin Medical University, 22 Qixiangtai Road, Heping, Tianjin 300070, P.R. China

E-mail: dengweimin@tijmu.edu.cn

Key words: autocrine, interferon- $\gamma$, estrogen receptor $\beta$, breast cancer cell line MCF-7 proliferation related to breast cancer development, through actions mediated by two estrogen receptor subtypes, ER $\alpha$ and $\operatorname{ER} \beta$ (reviewed in ref. 3). Although both estrogen receptors (ERs) share homology in their DNA and ligand-binding domains, they are the products of independent genes (reviewed in refs. 4,5). Moreover, unlike ER $\alpha$ whose expression is limited to breast epithelial cells, ER $\beta$ expression is widely distributed, not only in epithelial cell nuclei of normal and malignant glands but also in stromal and endothelial cell nuclei and in the myoepithelium of normal glands (6). These observation are consistent with the concept that ER $\beta$ may have a biological role distinct from $E R \alpha$.

Generally, ER $\alpha$ is the key ER contributing to the onset and progression of breast cancer and is a good prognostic marker predicting the likelihood of the patient response to adjuvant endocrine therapy (reviewed in refs. 7,8). $E R \beta$ is a negative modulator of ER $\alpha$, suppressing ER $\alpha$ transcription and inhibiting the sensitivity to estrogen, thus being regarded as a protective factor in the development of endocrine tumors including breast cancer (reviewed in refs. 9,10). However, there are conflicting studies regarding these ERs. ER $\alpha$-positive breast cancers seem to show less invasiveness and more favorable prognosis $(7-9,11,12)$, and a significant loss of ER $\beta$ expression is observed in a proportion of invasive carcinomas (6). Clinical-based studies have shown that $\sim 30 \%$ of ER $\alpha$-positive breast cancer cells do not respond to first-line endocrine therapies, and the majority of relapsing tumors still expresses ER $\alpha$ (reviewed in ref. 13). Thus, the role of ER subtypes in the progression and endocrine resistance of breast cancer has not been clearly elucidated.

Cytokines are proteins or peptides mainly produced by immune cells, which can promote the expression of a variety of genes involved in the survival or death of different target cells (14). In the tumor microenvironment, IL-4 or IFN- $\gamma$ has been shown to exert both positive and negative effects on the development and progression of cancer $(15,16)$. There is evidence suggesting that the IL-4 receptor (IL-4R) and the IFN- $\gamma$ receptor (IFN- $\gamma \mathrm{R}$ ) are detected on most immune and epithelial cells and a variety of human tumors of epithelial origin (17-19). Various studies illustrated that IL-4R expression level in tumor cells is much higher than in normal cells (20-24). 
Tumor cells are often surrounded by infiltrating inflammatory cells, particularly lymphocytes and macrophages, which are the main sources of cytokines. Notably, immunohistochemistry and cell-based studies in vitro show tumor tissues and tumor cell lines, including pancreatic, prostate, breast and bladder cancer, may be another source of cytokines in the tumor microenvironment $(14,25,26)$. Recently, the novel immunoediting theory emphasizes the dynamic interaction between the host immune system and the developing tumor. The theory points out that substances produced by tumor tissues contribute to suppressing antitumor immunity, which may provide an obstacle for exploring antitumor cytokine approaches (15). In thyroid cancer, the presence of IL-4 and IL-10 in the tumor microenvironment contributes to thyroid cancer cell survival and proliferation (27). Furthermore, several investigators have provided evidence that there is a correlation between IL-4 expression and local intracrine activity of estradiol (E2) as well as the expression of estrogen receptor in breast cancer. In the different breast cancer cell lines ZR-75-1 and T-47D, IL-4 shows increasing or decreasing effect on sex steroid production, respectively (28). In addition, intratumoral IL-4 levels tend to be negatively correlated with the level of hormone receptor, which seems to indicate crosstalk between cytokine receptors and ER may result in ligand-independent activation of ER signaling pathways (29).

Based on these studies demonstrating interactions between ERs and cytokine pathways, we evaluated interaction between the two ERs and the cytokines IL- 4 and IFN- $\gamma$, and whether this interaction modulates malignant behavior.

\section{Materials and methods}

Cell lines and cell culture. Human breast cancer MCF-7 and MDA-MB-231 cell lines were obtained from the American Type Culture Collection. Cells were cultured in RPMI-1640 containing $10 \%$ fetal bovine serum (FBS) (both from Life Technologies, Inc., Gaithersburg, MD, USA).

Cell transfection with pGenesil-ER $\alpha$ small interfering $R N A$ (siRNA), pGenesil-ER $\beta$ siRNA and pGenesil-scrambled siRNA vectors and generation of stable cell lines. Using the pGenesil-1 vector encoding enhanced green fluorescent protein and kanamycin/neomycin-resistance genes, pGenesil-ER $\alpha$ siRNA, pGenesil-ER $\beta$ siRNA and pGenesil-scrambled siRNA plasmids were constructed by Wuhan Genesil Biotechnology Co., Ltd. The sense sequences of the ER $\alpha$ siRNA pair (underlined sequence) were as follows: 5'-GA TCCG(CTCATCCTCTCCCACATCA)TTCAAGACG(TGA TGTGGGAGAGGATGAG)TTTTTTGTCGACA-3', and the antisense sequence of the ER $\alpha$ siRNA was, 5'-AGCTTGTCG TACAAAAAA(CTCATCCTCTCCCACATCA)CGTCTTG AA(TGATGTGGGAGAGGATGAG)CG-3'. The sense sequences of the ER $\beta$ siRNA pair (underlined sequence) were as follows: 5'-GATCC(GCCCTGCTGTGATGAATTA)TTCAA GACG(TAATTCATCACAGCAGGGC)TTTTTTGTCGACA-3', and the antisense sequences of the ER $\beta$ siRNA were: 5'-AGCT TGTCGACAAAAAA(GCCCTGCTGTGATGAATTA)CGT CTTGAA(TAATTCATCACAGCAGGGC)G-3'. The sense sequences of the scrambled siRNA pair (underlined sequence) were as follows: 5'-GATCC(GACTTCATAAGGCGCATGC)
TTCAAGACG(GCATGCGCCTTATGAAGTC)TTTTTTGT CGACA-3', and the antisense sequence of the scrambled siRNA was: 5'-AGCTTGTCGACAAAAAA(GACTTCATAA GGCGCATGC)CGTCTTGAA(GCATGCGCCTTATGAAG TC)G-3'. To generate the stable ER $\alpha$ siRNA or ER $\beta$ siRNA clones in MCF-7 cells, the pGenesil-ER $\alpha$ siRNA or pGenesil-ER $\beta$ siRNA construct was transfected into MCF-7 cells expressing endogenous ER $\alpha$ and ER $\beta$ by Lipofectamine $^{\mathrm{TM}} 2000$ (Invitrogen, San Diego, CA, USA), according to the manufacturer's protocol. MCF-7 cells $\left(4 \times 10^{5}\right)$ were plated into 6-well plates until 90-95\% confluence before transfection and were then transfected with $4 \mu \mathrm{g}$ of pGenesil-ER $\alpha$ siRNA or pGenesil-ER $\beta$ siRNA. Selection for the neomycin gene was initiated $48 \mathrm{~h}$ after transfection by adding $400 \mu \mathrm{g} / \mathrm{ml}$ of $\mathrm{G} 418$ (Invitrogen) to the supplemented culture medium. This selection medium was changed every 2 days for 4 weeks, until all non-transfected cells died. Resistant cell clones were isolated and expanded for further characterization. pGenesil-scrambled siRNA was also transfected into MCF-7 cells as non-specific siRNA control.

Treatment of human breast cancer MCF-7 cells in the absence or presence of rhIFN- $\gamma$ or rhIL-4. MCF-7 cells were cultured in $60-\mathrm{mm}$ culture dishes $\left(1 \times 10^{6}\right.$ cells/dish) overnight, and then switched to medium containing $1 \%$ FBS for $24 \mathrm{~h}$. The cells were treated in $1 \%$ FBS with rhIFN- $\gamma(0.1,1,10,50,100$ or $250 \mathrm{ng} / \mathrm{ml})$ or rhIL-4 (0.1, 1, 5, 10, $25 \mathrm{ng} / \mathrm{ml})$ (Sigma, St. Louis, MO, USA) in $0.1 \%$ BSA-phosphate-buffered saline (PBS) for $1,2,3$ or 4 days. Control cells were treated with $0.1 \%$ bovine serum albumin (BSA) (Sigma)-PBS vehicle as previously described.

Tamoxifen (TAM) treatment of human breast cancer MCF-7 cells and their stable transfected clones with ER $\alpha$ siRNA, ER $\beta$ siRNA or scrambled siRNA. MCF-7 cells and their stable transfected clones with ER $\alpha$ siRNA, ER $\beta$ siRNA or scrambled siRNA were plated into 96 -well ( $4 \times 10^{3}$ cells/well) plates overnight, and then switched to medium containing $1 \%$ FBS for $24 \mathrm{~h}$. The cells were treated in $1 \%$ FBS with TAM $(0.1$, $0.5,1,5$ and $10 \mu \mathrm{M}$ ) (Sigma) in dimethylsulfoxide (DMSO) for $24 \mathrm{~h}$, or pretreated in $1 \%$ FBS with rhIFN- $\gamma(0.5$ or $100 \mathrm{ng} / \mathrm{ml})$ for $72 \mathrm{~h}$ and then treated with TAM $(10 \mu \mathrm{M})$ for $24 \mathrm{~h}$. The final DMSO concentration was $0.1 \%$. Control cells were treated with DMSO vehicle or $0.1 \%$ BSA-PBS vehicle as previously described.

Semi-quantitative RT-PCR. Total RNA was isolated from cells with TRIzol (Invitrogen) according to the manufacturer's instructions. Primer sequences were designed by Vector NTI 8 software and synthesized by Takara Biotechnology Co., Ltd. (Dalian, China). The primer sequences were as follows: ER $\alpha$, 5'-AACAAAGGCATGGAGCATCTGT-3' (forward) and 5'-GTGATGTAATACTTTTGCAAGG-3' (reverse); for ER $\beta$, 5'-GCGCTGTCTGCAGCGATTACGC-3' (forward) and 5'-CACCATTCCCACTTCGTAACAC-3' (reverse); for Bcl-2, 5'-TGCACCTGACGCCCTTCAC-3' (forward) and 5'-AGA CAGCCAGGAGAAATCAAACAG-3' (reverse); for Bcl-xL, 5'-ATGTCTCAGAGCAACCGGGAGC-3' (forward) and 5'-GCGATCCGACTCACCAATACCT-3' (reverse); for XIAP, 5'-ATGATACCATCTTCCAAAATCC-3' (forward) and 
5'-TTTCTGTAATGAAGTCTGACTT-3' (reverse); for $\beta$-actin, 5'-TGGAATCCTGTGGCATCCATGAAAC-3' (forward) and 5'-TAAAACGCAGCTCAGTAACAGTCC-3' (reverse). One-Step RNA PCR kit (AMV) (Takara Biotechnology) was used for RT-PCR. PCR products were fractionated on $1.5 \%$ agarose gel and analyzed with Quantity One 4.5.6 software (Bio-Rad, Hercules, CA, USA). The results were normalized against $\beta$-actin and presented as target mRNA: $\beta$-actin ratio.

Western blot analysis. Cells were lysed in ice-cold RIPA buffer $(150 \mathrm{mM} \mathrm{NaCl}, 1 \%$ Nonidet P-40, $0.5 \%$ deoxycholate, $0.1 \%$ SDS, $50 \mathrm{mM}$ Tris- $\mathrm{HCl} \mathrm{pH} 8.0,1 \mathrm{mM}$ PMSF, $10 \mu \mathrm{g} / \mathrm{ml}$ leupeptin and $100 \mu \mathrm{g} / \mathrm{ml}$ aprotinin) for $45 \mathrm{~min}$ on ice. The lysates were centrifuged to remove cellular debris. Supernatants were analyzed for protein concentration using the bicinchoninic acid assay kit (Pierce Biochemicals, Rockford, IL, USA). Total cell lysates ( $40 \mu \mathrm{g}$ ) were subjected to $8-10 \%$ SDS-PAGE gels and analyzed by blotting with rabbit polyclonal anti-ER $\alpha$ and anti-ER $\beta$ antibody (Santa Cruz Biotechnology, Santa Cruz, CA. USA), respectively. Membranes were stripped by incubating with stripping buffer at $50^{\circ} \mathrm{C}$ for $30 \mathrm{~min}$ and then blotted with mouse monoclonal anti- $\beta$-actin antibody (Sigma). Immunodetection was performed using the corresponding secondary HRP-conjugated antibody, and HRP activity was detected using chemiluminescent substrate kit (SuperSignal ${ }^{\circledR}$ West Pico Trial kit; Pierce Biochemicals).

MTT assay. Cell proliferation was measured with MTT assay. Briefly, human breast cancer cells were cultured into 96-well plates at $4 \times 10^{3}$ cells/well and treated with rhIFN- $\gamma$, rhIL-4 or TAM as previously described. After treatment, the cells were incubated with $100 \mu \mathrm{l}$ of MTT solution $(0.5 \mathrm{mg} / \mathrm{ml}$; Sigma) for $4 \mathrm{~h}$ at $37^{\circ} \mathrm{C}$. After centrifugation, $100 \mu \mathrm{l}$ of $0.04 \mathrm{M}$ $\mathrm{HCl}$-isopropanol was added. The absorbance was measured at $492 \mathrm{~nm}$ using ELISA microplate reader. Data represent the average absorbance of five wells in one experiment. The experiment was repeated twice with similar results.

Enzyme-linked immunosorbent assay (ELISA). To evaluate the in vitro production of IFN- $\gamma$ and IL-4 by breast cancer cells, $1 \times 10^{5}$ cells were seeded into 24 -well plates overnight, and the supernatants were collected and clarified by centrifugation. The level of IFN- $\gamma$ and IL- 4 was measured using ELISA kits (R\&D Systems, Minneapolis, MN, USA) according to the manufacturer's instructions.

Cell cycle distribution assay. Cells were cultured in serum-free medium for $6 \mathrm{~h}$, and then harvested and resuspended in PBS containing $0.1 \mathrm{M}$ propidium iodide solution, $0.1 \%$ Triton X-100 (Sigma) and 2\% RNase A. After incubation on ice, in the dark, for $2 \mathrm{~h}$, the samples were analyzed by flow cytometry. One hundred thousand events were recorded and the proportion of cells in various phases of the cell cycle was analyzed using the ModFit LT DNA analysis software (Becton-Dickinson, San Jose, CA, USA).

Soft-agar colony formation assay. To assess the effect of anchorage-independent growth, cells $\left(1 \times 10^{4}\right.$ cells/6-well plate) were grown in soft agar for 14 days at $37^{\circ} \mathrm{C}$ using a two layer agar system and the number of colonies quantitated as previously described (30).

In vitro cell adhesion assay. As previously described (30), 96-well plates were pre-coated with Matrigel overnight at $37^{\circ} \mathrm{C}$. After blocking with $2 \%$ BSA solution for $1 \mathrm{~h}$ at $37^{\circ} \mathrm{C}$, $4 \times 10^{3}$ cells in $100 \mu 1$ of serum-free RPMI-1640 medium containing $0.1 \%$ BSA were placed into the wells precoated with the reconstituted matrix for $1 \mathrm{~h}$ at $37^{\circ}$. The cells were washed with PBS and the MTT assay was performed as previously described. Data represent the average absorbance of five wells in one experiment. The experiment was repeated twice with similar results.

Statistical analysis. Multiple comparisons were performed using one-way analysis of variance (ANOVA) with Fisher's protected least significant difference method for post hoc analysis. All statistical tests were two-sided. For all tests, the level of significance was set at $\mathrm{P}<0.05$. Statistical analysis was carried out using SPSS version 11.0 software.

\section{Results}

Knockdown of ER $\beta$ causes increased cell proliferation in $M C F-7$. In order to investigate the role of ER subtypes in the cell growth of human breast cancer cells, we first analyzed the expression of $E R \alpha$ and $E R \beta$ as well as the cell proliferation of two breast cancer cell lines, MCF-7 and MDA-MB-231. As shown in Fig. 1A, not only ER $\alpha$ but also ER $\beta$ was expressed at the medium level in MCF-7, whereas in MDA-MB-231, ER $\beta$ was expressed at a significantly higher level than that in MCF-7. MTT assay demonstrated that cell proliferation ability in MCF-7 was stronger than that in MDA-MB-231 after culturing for 4 days (Fig. 1B). These data are consistent with the possibility that ER $\alpha$ is a positive factor in promoting tumor growth; whereas, ER $\beta$ is a negative factor.

As previous studies reported, the expression of ER subtypes may account for the confusion regarding the ER $\beta$ role in cell proliferation. To determine whether expression of ER subtypes correlates with cell proliferation, MCF-7 cells, which express both ER $\alpha$ and $\beta$, were chosen to determine the impact of altering ER $\alpha$ and $\beta$ expression on cell growth. Stable clones with efficient knockdown of $\mathrm{ER} \alpha$ and $\beta$ were made, two clones \#2 with maximum knockdown of ER $\alpha$ or ER $\beta \sim 77.7$ or $68.3 \%$ (i.e., $\mathrm{M} / \mathrm{si} \alpha$ and $\mathrm{M} / \mathrm{si} \beta$ cells) and scrambled siRNA-transfected MCF-7 cells (i.e., M/sc cells) were chosen for subsequent studies (Fig. 1C). As illustrated in Fig. 1D, compared with the control cells (M/sc), cell proliferation decreased in $\mathrm{M} / \mathrm{si \alpha}$, which relatively overexpressed $\mathrm{ER} \beta$, whereas that in $\mathrm{M} / \mathrm{si} \beta$, which relatively overexpressed ER $\alpha$, increased. The effect of ER subtypes on cell proliferation was confirmed with FACS analysis of synchronized MCF-7 cells (Fig. 1E). Compared with the control cells, $\mathrm{M} / \mathrm{si} \alpha$ cells had a significant increase in the G1 phase and decrease in the G2+S phase, whereas $\mathrm{M} / \mathrm{si} \beta$ cells had a significant decrease in the G1 phase and increase in the $\mathrm{G} 2+\mathrm{S}$ phase. These data suggest that knockdown of ER $\beta$ promotes the proliferation of MCF-7 by altering cell cycle distribution. We next analyzed the mRNA levels of apoptosis suppressor genes (Fig. 1F). Compared with the corresponding control cells, the expression of $\mathrm{Bcl}-2, \mathrm{Bcl}-\mathrm{xL}$ 
A
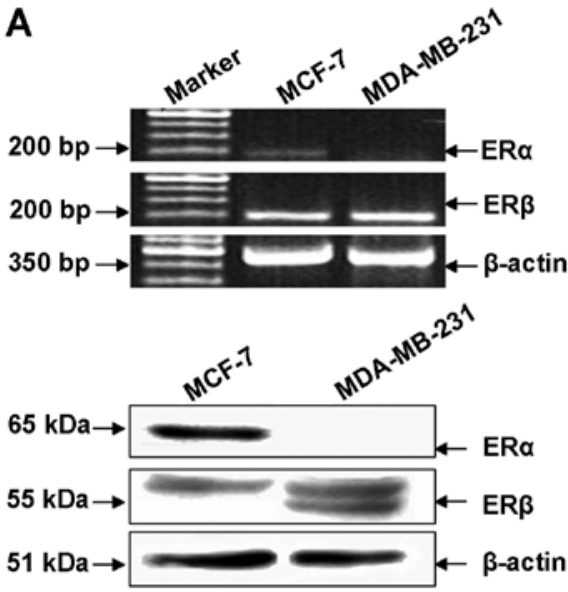

B

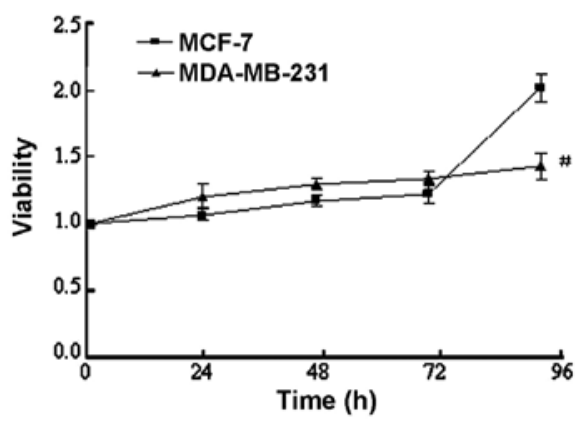

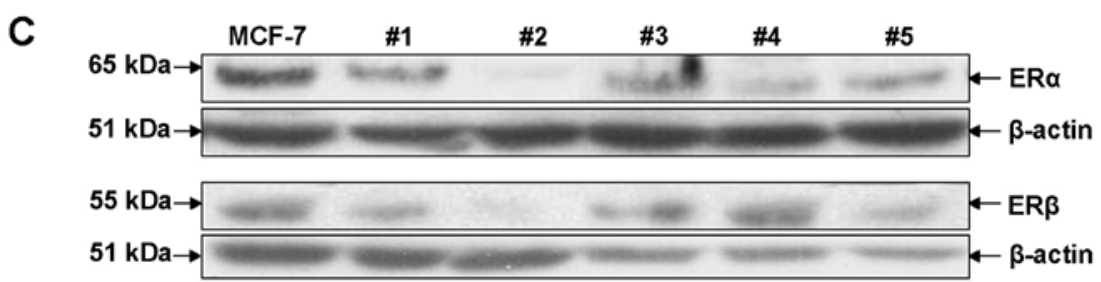

D

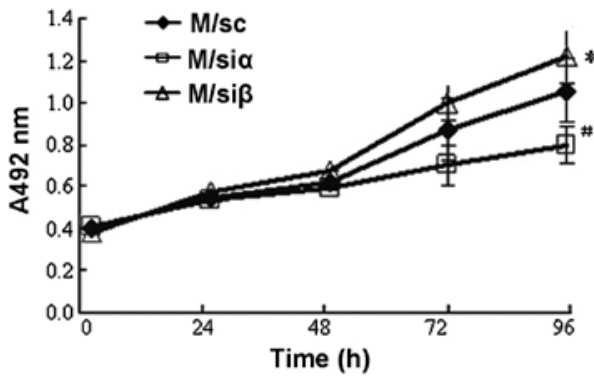

$\mathbf{F}$

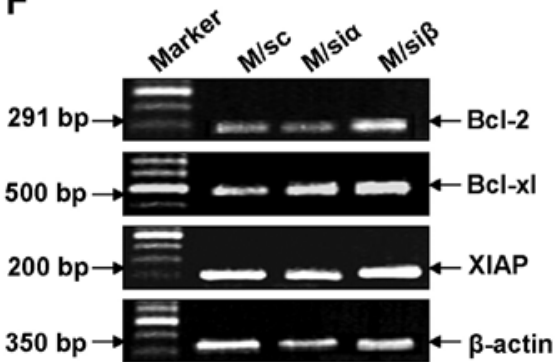

E
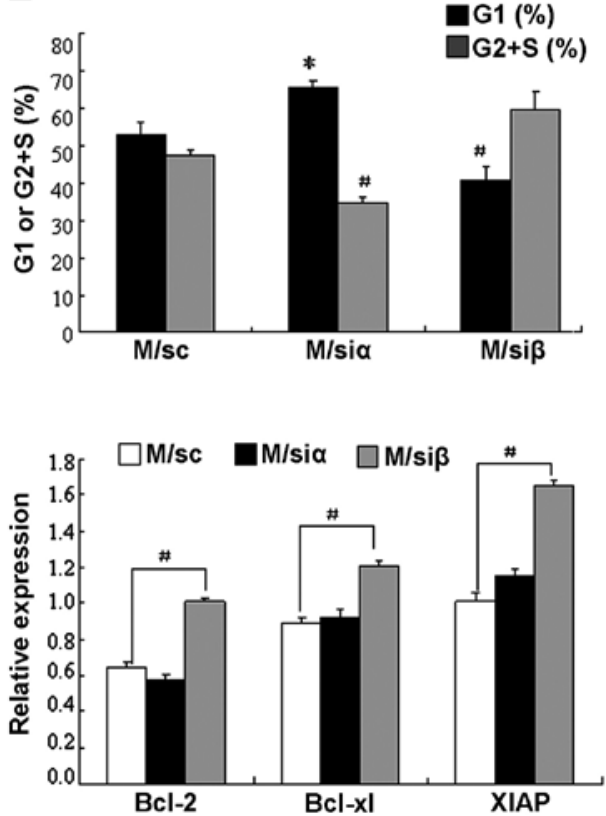

Figure 1. Regulation of cell growth in human breast cancer cell lines by ER subtypes. (A) Detection of ER $\alpha$ and $\beta$ mRNA and proteins in human breast cancer cell lines MCF-7 and MDA-MB-231 by semi-quantitative RT-PCR and western blot analysis. The target gene expression was normalized using $\beta$-actin as control of mRNA level. The target protein levels were normalized against $\beta$-actin as control for variance in sample loading and transfer. The experiment shown is representative of three separate experiments with similar results. (B) Cell proliferation of MCF-7 and MDA-MB-231 was assayed by MTT test. Data are shown as the mean \pm SD of three experiments with sextuple samples. ${ }^{\#} \mathrm{P}<0.01$ compared with MCF-7. (C) Confirmation of transfection efficacy as well as expression level of ER $\alpha$ or $\beta$ protein in MCF-7 cells and their transfectants. MCF-7 cells were stably transfected with siRNA targeting human ER $\alpha$ or $\beta$ gene to silence corresponding ER subtype. Stable MCF-7 transfected clones including \#1-5 were obtained and screened by western blotting with anti-ER $\alpha$ or anti-ER $\beta$ antibody. Two stable transfected clones \#2, with maximum knockdown of ER $\alpha$ or ER $\beta$ protein $\sim 77.7$ and $68.3 \%$, respectively (i.e., M/si $\alpha$ and M/si $\beta$ cells), and scrambled siRNA-transfected MCF-7 cells (i.e., M/sc cells) were chosen for subsequent studies. (D) Cell proliferation of MCF-7 transfectants after culturing for $0,24,48,72$ or $96 \mathrm{~h}$ was detected by MTT assay. Data are shown as the mean \pm SD of two separate experiments with sextuple samples. (E) Cell cycle distribution in MCF-7 transfectants after culturing for $96 \mathrm{~h}$ were assayed by flow cytometry. Black bar, G1 phase; gray bar, G2+S phase. (F) mRNA levels of apoptosis suppressor genes in MCF-7 transfectants after culturing for $96 \mathrm{~h}$ were determined by semi-quantitative RT-PCR method. White bar, M/sc; black bar, $\mathrm{M} / \mathrm{si \alpha}$; gray bar, $\mathrm{M} / \mathrm{si} \beta$. The experiment shown is representative of three independent experiments with similar results. ${ }^{*} \mathrm{P}<0.05$, ${ }^{\sharp} \mathrm{P}<0.01$ compared with the control vector-tranfected MCF-7 cells.

and XIAP increased significantly in $\mathrm{M} / \mathrm{si} \beta$ cells $(\mathrm{P}<0.01)$ whereas no difference was observed in $\mathrm{M} / \mathrm{si} \alpha$ cells.
Knockdown of ER $\beta$ in MCF-7 enhances tumorigenicity and adhesion ability in vitro. To ascertain the biological effects 


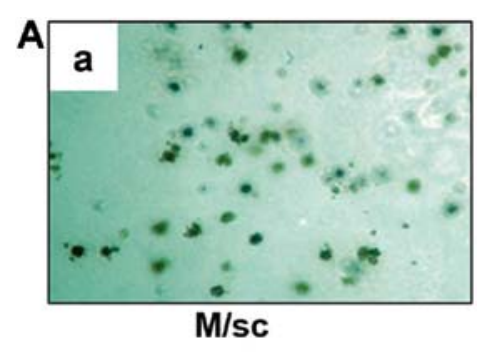

B

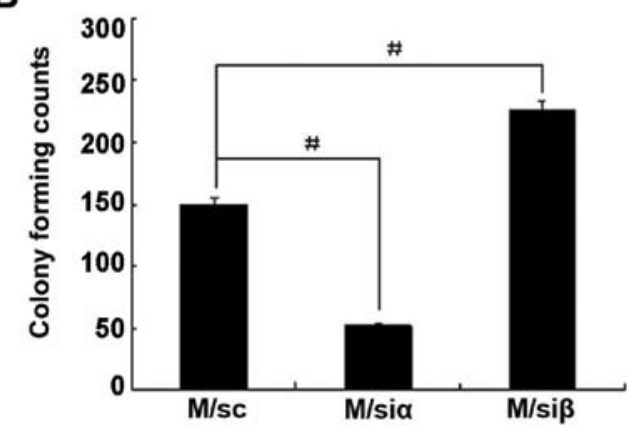

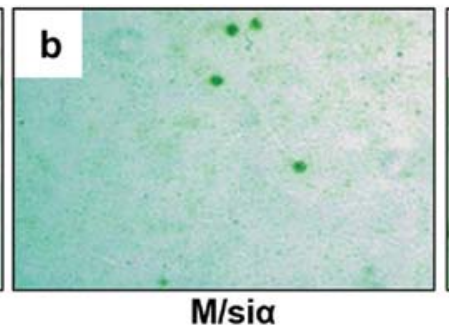

C

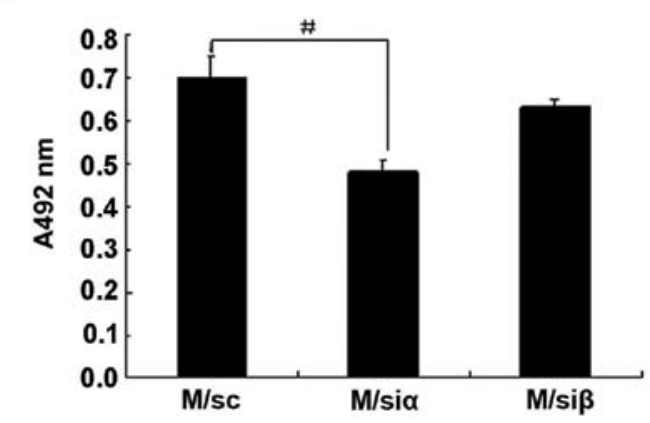

Figure 2. Regulation of anchorage-independent growth and adhesion of MCF-7 transfectants by ER subtypes. (A) Detection of anchorage-independent growth in MCF-7 transfectants by soft-agar colony formation assay. The image shown is representative of three independent experiments with similar results. Magnification, $x 40$. (B) The colony counts of MCF-7 transfectants in soft agar. (C) Detection of adhesion in MCF-7 transfectants by cell adhesion assay. The adhesion of cells was measured by detecting absorbance at $492 \mathrm{~nm}$ of cells adhering to Matrigel-coated 96 -well plates. Data are shown as the mean \pm SD of three separate experiments. ${ }^{*} \mathrm{P}<0.05,{ }^{\#} \mathrm{P}<0.01$ compared with the control vector-tranfected MCF-7 cells.

of ER subtypes on tumorigenicity of MCF-7, we assessed the anchorage-independent growth of stable transfectants and the control cells in soft agar. As shown in Fig. 2A and B, the number of colonies formed by $\mathrm{M} / \mathrm{si} \alpha$ cells was significantly decreased ( $\sim 66.7 \%$ decrease) compared to those formed by the M/sc cells. However, the number of colonies formed by $\mathrm{M} / \mathrm{si} \beta$ cells was increased ( $~ 80.1 \%$ increase) compared to those formed by the $\mathrm{M} / \mathrm{sc}$ cells. These findings provide direct evidence that knockdown of ER $\beta$ promotes tumorigenicity of MCF-7 cells.

Adhesion is a key function in the development of metastasis. Accordingly, to examine whether ER subtype expression correlates with adhesion ability of breast cancer cells, we measured adhesion of MCF-7 stable transfectants and the control cells. As shown in Fig. 2C, compared with M/sc cells, ability of cell adhesion in $\mathrm{M} / \mathrm{si}$ cells decreased $(\mathrm{P}<0.01)$ markedly, while that in $\mathrm{M} / \mathrm{si} \beta$ cells had no change. These results suggest that the increasement of relative expression level of ER $\beta$ by knockdown of ER $\alpha$ may have an enhancing effect on adhesion ability of MCF-7 cells, although direct knockdown of $\mathrm{ER} \beta$ plays only a small role.

Positive correlation exists between IFN- $\gamma$ at autocrine level and $E R \beta$ in MCF-7. Although some clinical-based studies indicate the correlation between cytokine expression in tumor microenvironment and ER levels in tumor tissues, the cell-based association study on IFN- $\gamma$ and IL- 4 autocrine levels and ER subtypes in breast cancer have not been previously reported. Accordingly, to examine whether ER subtype expression correlates with autocrine IFN- $\gamma$ and IL-4 in human breast cancer cells, we first examined production of IFN- $\gamma$ and IL-4 in MCF-7 and MDA-MB-231. As shown in Fig. 3A, IFN- $\gamma$ production in MDA-MB-231 was markedly higher than that in MCF-7. However, there was no difference found in IL-4 secretion. The data illustrated in Figs. 1A and 3A indicate that autocrine expression of IFN- $\gamma$ in breast cancer cells is inversely correlated with $\mathrm{ER} \alpha$; whereas, positively correlated with ER $\beta$. We then investigated the secretion of IFN- $\gamma$ and IL-4 in MCF-7 and its stable transfectants. Consistent with the above results, compared with the corresponding control cells, IFN- $\gamma$ production in $\mathrm{M} / \mathrm{si} \alpha$ cells was significantly increased $(\mathrm{P}<0.01)$; whereas, that in $\mathrm{M} / \mathrm{si} \beta$ cells was significantly decreased $(\mathrm{P}<0.01)$ (shown in Fig. $3 \mathrm{~B}$ and $\mathrm{C}$ ). These results provide further support that IFN- $\gamma$ expression is differentially regulated by ER subtype.

rhIFN- $\gamma$ and rhIL-4 have effects on biological behavior of MCF-7 cells. Tumor cells may produce a certain level of cytokines to suppress antitumor immunity in tumor microenvironment. IFN- $\gamma$ and IL-4 have been shown to exert negative or positive effects on the progression of cancer. Based on the above possibility, we first examined the impact of IFN- $\gamma$ and IL-4 on MCF-7 cell growth (Fig. 4A and B). As expected, IFN $-\gamma$ significantly inhibited proliferation at 100 and $250 \mathrm{ng} /$ $\mathrm{ml}$ at 96 -h time point. In contrast, IL-4 significantly augmented cell growth at 10 and $25 \mathrm{ng} / \mathrm{ml}$ at the same time point.

To explore whether IFN- $\gamma$ and IL- 4 were able to modulate tumor cell growth by affecting the ER subtype expression in breast cancer cells, we then investigated the protein levels of $\mathrm{ER} \alpha$ and $\mathrm{ER} \beta$ in MCF-7, in the absence or presence of $\mathrm{rhIFN}-\gamma(100 \mathrm{ng} / \mathrm{ml})$ or $\mathrm{rhIL}-4(10 \mathrm{ng} / \mathrm{ml})$ for $96 \mathrm{~h}$, respectively. As shown in Fig. $4 \mathrm{C}$, rhIFN $-\gamma$ markedly enhanced expression of ER $\beta$ ( 1.72-fold); whereas, rhIL-4 decreased expression of $\operatorname{ER} \beta(\sim 0.57$-fold $)$, compared to the vehicle control, whereas, neither IFN- $\gamma$ nor IL- 4 affected $\mathrm{ER} \alpha$ protein level. Furthermore, investigation illustrated that after treatment for $96 \mathrm{~h}, 100 \mathrm{ng} / \mathrm{ml} \mathrm{rhIFN}-\gamma$ may induce cell 
A

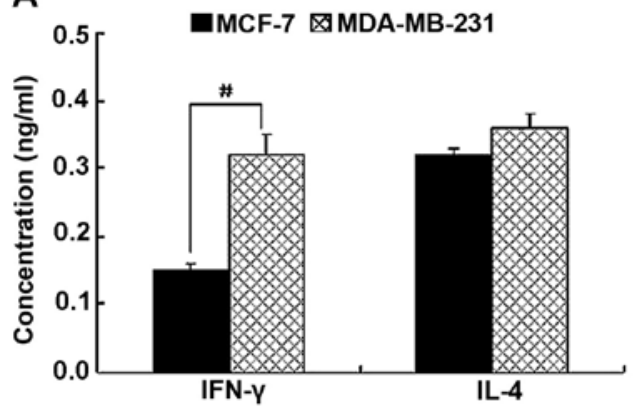

C

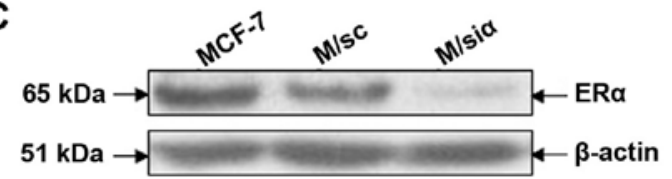

B
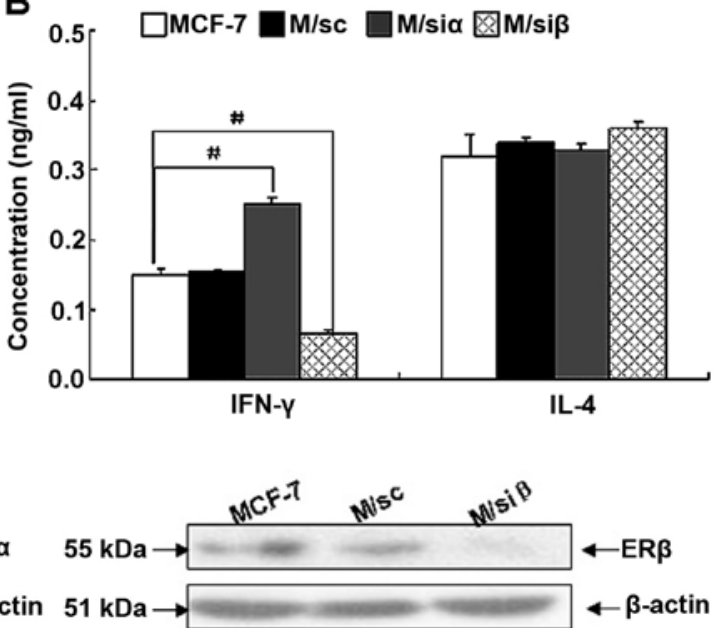

Figure 3. The correlation between expression of ER subtypes and autocrine level of IFN- $\gamma$ and IL-4 in human breast cancer cell lines. (A) Detection of autocrine levels of IFN- $\gamma$ and IL-4 in the breast cancer cell lines MCF-7 and MDA-MB-231 by ELISA as described above. Black bar, MCF-7; grid bar, MDA-MB-231. (B) Detection of autocrine levels of IFN- $\gamma$ and IL-4 in parental and MCF-7 stable transfectants by ELISA. Blank bar, MCF-7; black bar, M/sc; gray bar, M/si ; grid bar, M/siß. (C) Detection of protein expression of ER subtypes in parental and MCF-7 stable transfectants by western blotting as described above. The experiment shown is representative of three independent experiments with similar results. Data are shown as the mean $\pm \mathrm{SD}$ of three separate experiments with sextuple samples. ${ }^{\text {}} \mathrm{P}<0.01$ compared with MCF-7.

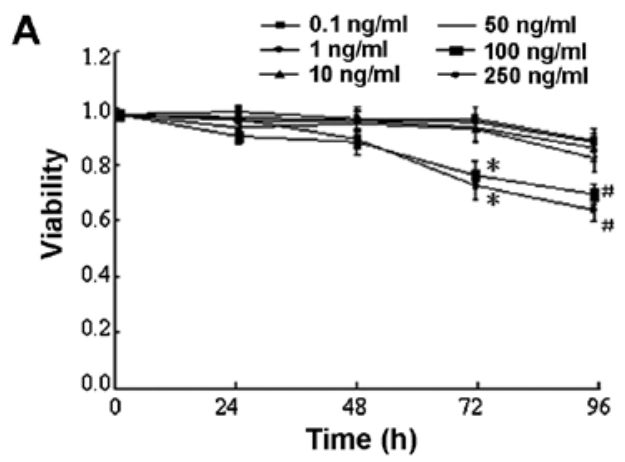

C

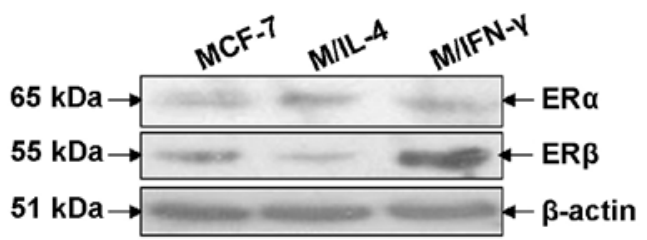

D

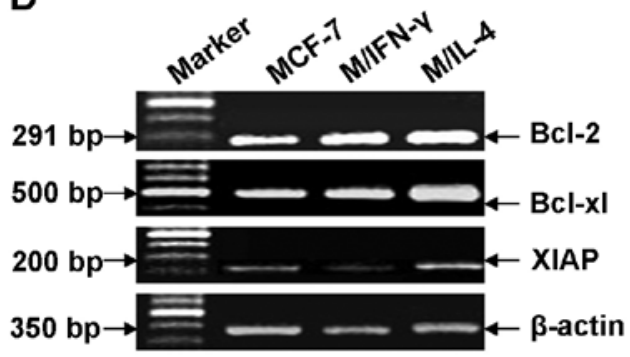

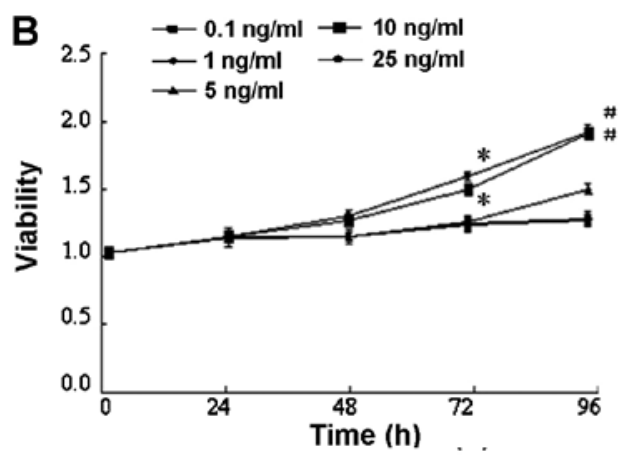

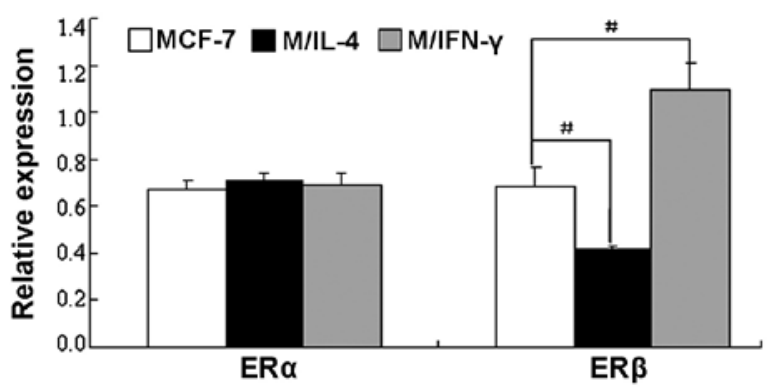

E

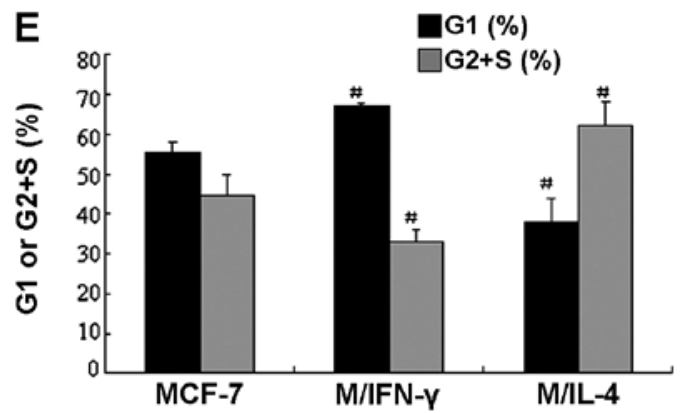

Figure 4. Effects of rhIFN- $\gamma$ and rhIL-4 on cell viability, cell cycle and the apoptosis suppressor gene mRNA expression in MCF-7. (A and B) Detection of cell proliferation of MCF-7 after treated with rhIFN- $\gamma$ or rhIL-4 for 24, 48, 72 and 96 h by MTT assay. (A) rhIFN- $\gamma$; (B) rhIL-4. (C) The protein levels of ER subtypes were determined by western blotting assay. White bar, vehicle; black bar, $10 \mathrm{ng} / \mathrm{ml} \mathrm{rhIL}-4$; gray bar, $100 \mathrm{ng} / \mathrm{ml} \mathrm{rhIFN}-\gamma$. (D) mRNA levels of the apoptosis suppressor genes were detected by semi-quantitative RT-PCR. (E) Cell cycle distribution was analyzed by flow cytometry. Black bar, G1 phase; gray bar, G2+S phase. The image is representative of three independent experiments with similar results. Data are shown as the mean \pm SD of three separate experiments with sextuple samples. ${ }^{*} \mathrm{P}<0.05,{ }^{\#} \mathrm{P}<0.01$ compared with vehicle control. 


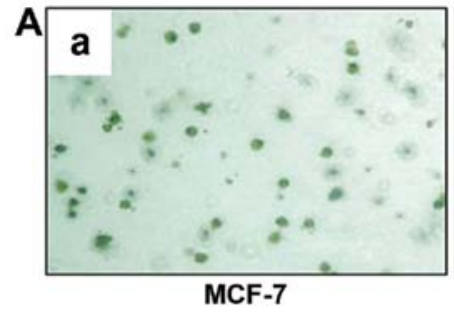

B

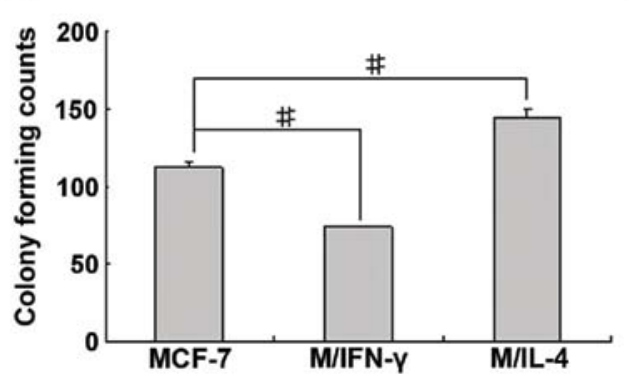

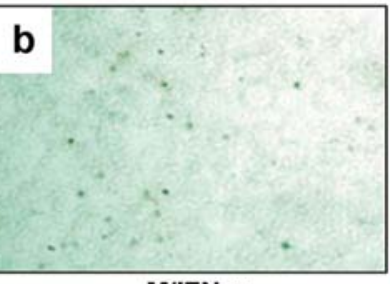

MIIFN-Y

C

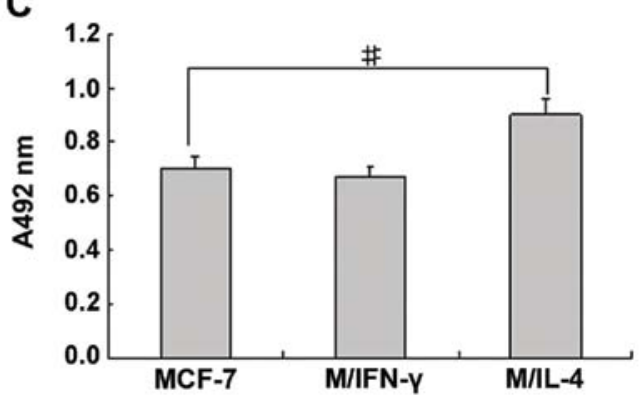

Figure 5. Effects of rhIFN- $\gamma$ and rhIL-4 on anchorage-independent growth and adhesion of MCF-7. (A) Detection of anchorage-independent growth in MCF-7 treated with vehicle (a) or $100 \mathrm{ng} / \mathrm{ml} \mathrm{rhIFN-} \gamma$ (b) or $10 \mathrm{ng} / \mathrm{ml} \mathrm{rhIL}-4$ (c) by soft-agar colony formation assay. The image shown is representative of three independent experiments with similar results. Magnification, x40. (B) The colony counts of MCF-7 after above treatment in soft agar. White bar, vehicle; black bar, $100 \mathrm{ng} / \mathrm{ml}$ rhIFN- $\gamma$; gray bar, $10 \mathrm{ng} / \mathrm{ml} \mathrm{rhIL}-4$. (C) Detection of adhesion in MCF-7 after the above treatment by cell adhesion assay. The adhesion of cells was measured by detecting absorbance at $492 \mathrm{~nm}$ of cells adhering to Matrigel-coated 96 -well plates. Data are shown as the mean \pm SD of three separate experiments. ${ }^{~} \mathrm{P}<0.01$ compared with vehicle control.

apoptosis and inhibit metastasis of human breast cancer cells; on the contrary, $10 \mathrm{ng} / \mathrm{ml} \mathrm{rhIL-4}$ is able to promote tumor cell growth and metastasis. As shown in Fig. 4D, rhIFN- $\gamma$ decreased mRNA level of the anti-apoptosis gene XIAP ( 0.32-fold), but IL-4 increased mRNA level of the anti-apoptotic genes Bcl-2 and Bcl-xL ( 1.38- and 1.97-fold, respectively). Cell cycle distribution analysis showed rhIFN- $\gamma$ increased the percentage of $\mathrm{G} 1$ phase $(66.9 \%)$ and decreased the percentage of $\mathrm{G} 2+\mathrm{S}$ phase $(33.1 \%)$ in MCF-7 compared with vehicle control (percentage of G1 and G2+S phase was 55.4 and $44.6 \%$, respectively, $\mathrm{P}<0.01)$; whereas, IL- 4 increased the cell proportion in the $\mathrm{G} 2+\mathrm{S}$ phase (percentage of $\mathrm{G} 1$ and $\mathrm{G} 2+\mathrm{S}$ phase was 37.8 and $62.2 \%$, respectively, $\mathrm{P}<0.01$ ) (Fig. 4E).

Furthermore, we ascertained whether IFN- $\gamma$ or IL- 4 had negative or positive effects on tumorigenicity and adhesion ability in MCF-7, respectively. As shown in Fig. 5A and B, compared with vehicle control, the number of colonies formed in soft agar by MCF-7 in the presence of IFN- $\gamma$ significantly decreased ( $33.9 \%$ decrease). However, the number of colonies formed in the presence of rhIL-4 significantly increased ( $28.6 \%$ increase). As illustrated in Fig. 5C, compared with vehicle control, adhesion ability of MCF-7 treated with rhIL-4 increased: whereas, no difference was found regarding that of MCF-7 treated with rhIFN- $\gamma$.

Autocrine level of IFN- $\gamma$ affects $m R N A$ expression of ER $\beta$ and the apoptosis suppressor gene Bcl-2. Based on the above studies (Fig. 3A and B), we found the autocrine production of IFN- $\gamma$ and IL-4 by MCF-7 and MDA-MB-231 is below $1 \mathrm{ng} / \mathrm{ml}$. We determined whether the level of IFN- $\gamma$ and IL-4 affect the expression of ER subtypes and the malignant behavior of breast cancer cells. To address this problem, we used conditioned-medium from $\mathrm{M} / \mathrm{si} \alpha$ or $\mathrm{M} / \mathrm{si} \beta$, or $0.5 \mathrm{ng} / \mathrm{ml}$ rhIFN- $\gamma$ or rhIL- 4 to treat MCF-7 cells for 4 days. Then mRNA
A

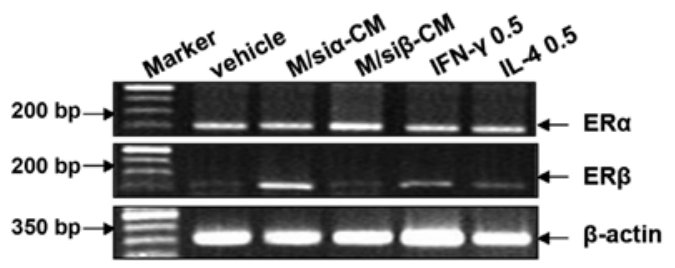

B

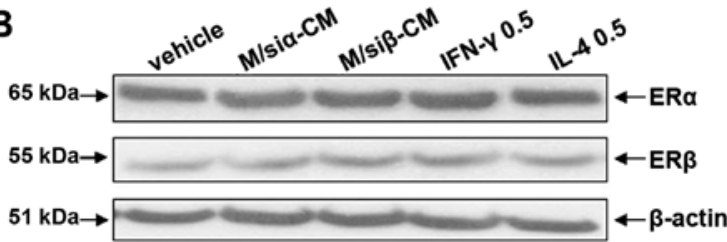

C

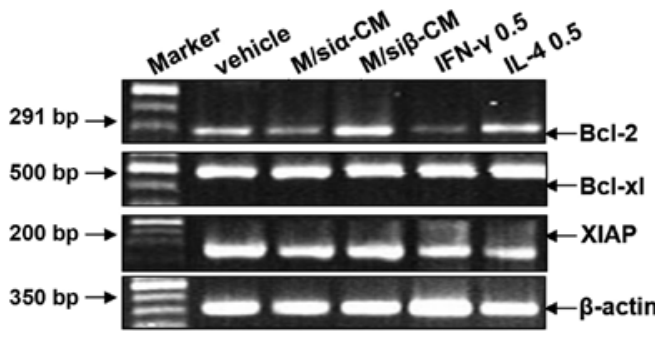

Figure 6. Effects of autocrine IFN- $\gamma$ and IL-4 on ER expression and the apoptosis suppressor gene mRNA expression in MCF-7. MCF-7 cells were treated with vehicle, conditioned medium from $\mathrm{M} / \mathrm{si \alpha}(\mathrm{M} / \mathrm{si} \alpha-\mathrm{CM}$, containing $\sim 0.25 \mathrm{ng} / \mathrm{ml} \mathrm{IFN}-\gamma)$ or $\mathrm{M} / \mathrm{si} \beta(\mathrm{M} / \mathrm{si} \beta-\mathrm{CM}$, containing $\sim 0.35 \mathrm{ng} / \mathrm{ml}$

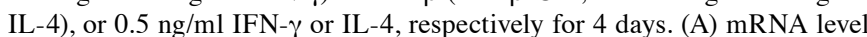
of ER by semi-quantitative RT-PCR as described above. (B) Protein level of ER by western blotting as described above. (C) mRNA level of apoptosis suppressor genes by semi-quantitative RT-PCR as described above. Target genes and protein levels were normalized against $\beta$-actin to control for variance in sample loading and transfer. The results are representative of three separate experiments with similar results.

and protein expression of ER subtypes and mRNA expression of the apoptosis suppressor genes were detected. As illustrated 
A

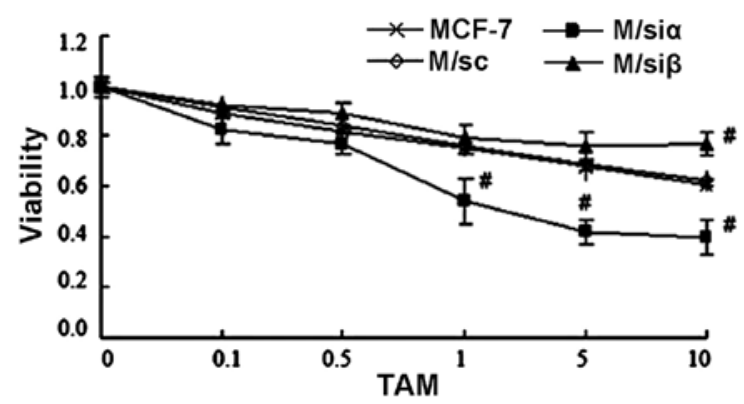

B

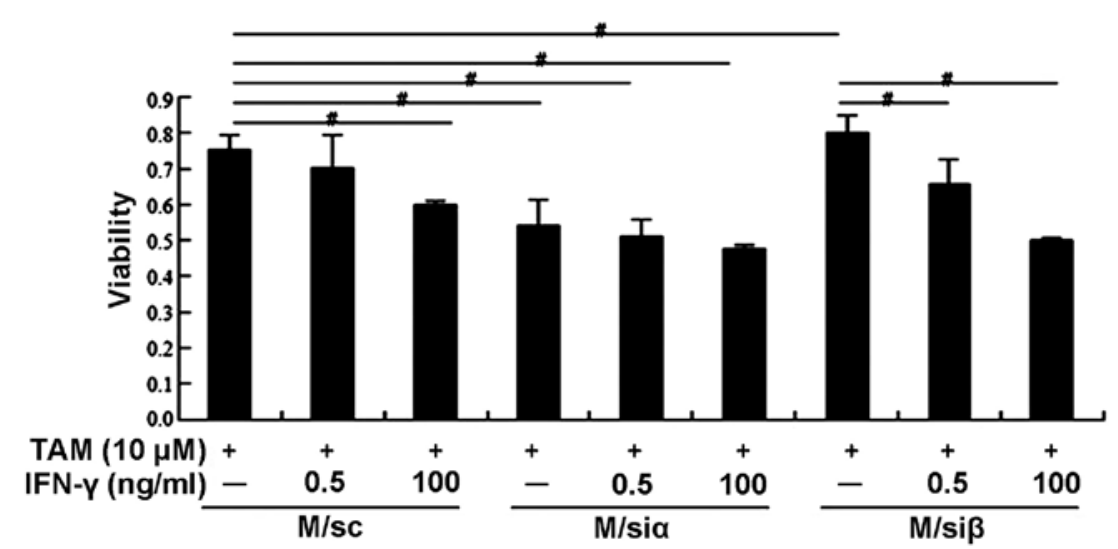

C
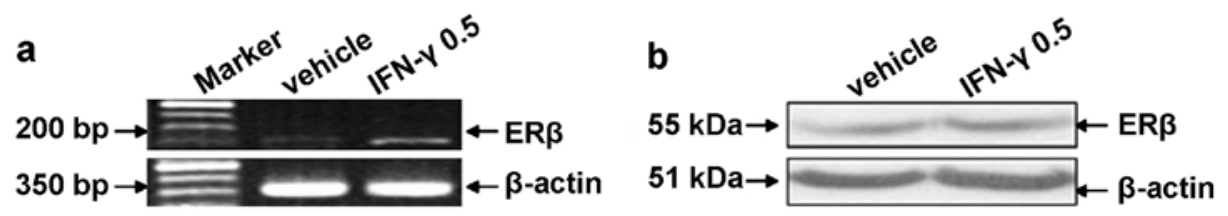

Figure 7. IFN- $\gamma$ promotes ER $\beta$ expression and upregulates the sensitivity to TAM of MCF-7 cells. (A) Viability of MCF-7 and their stable transfectants treated with TAM $(0.1,0.5,1,5$ and $10 \mu \mathrm{M})$ or vehicle for $24 \mathrm{~h}$. (B) Viability of MCF-7 cells and the stable transfectants after pretreated with rhIFN- $\gamma(0.5$ or $100 \mathrm{ng} / \mathrm{ml})$ or vehicle for $72 \mathrm{~h}$ and then treated with TAM $(10 \mu \mathrm{M})$ for $24 \mathrm{~h}$. Data are shown as the mean \pm SD of three separate experiments with sextuple samples. ${ }^{~} \mathrm{P}<0.01$ compared with vehicle control. (C) mRNA level (a) and protein level (b) of ER $\beta$ by semi-quantitative RT-PCR or western blotting assay as described above. The image shown is representative of three independent experiments with similar results.

in Fig. 6A, compared with control group, mRNA expression of ER $\beta$ in MCF-7 treated with conditioned-medium from $\mathrm{M} / \mathrm{si} \alpha$ (in which the level of IFN- $\gamma$ was $\sim 0.25 \mathrm{ng} / \mathrm{ml}$ ), or $0.5 \mathrm{ng} / \mathrm{ml} \mathrm{rhIFN}-\gamma$ was increased $(\sim 1.86$ - and 1.28 -fold, respectively); whereas, that in MCF-7 treated with conditioned medium of $\mathrm{M} / \mathrm{si} \beta$ (in which the level of IL- 4 was $\sim 0.35 \mathrm{ng} / \mathrm{ml}$ ) or $0.5 \mathrm{ng} / \mathrm{ml}$ rhIL-4 had no change. In contrast, the treatment had no effect on mRNA expression of ER $\alpha$. As illustrated in Fig. 6B, there was on difference in protein expression of $E R \alpha$ and $\beta$. In regards to apoptosis suppressor genes, Fig. $6 \mathrm{C}$ shows mRNA expression of Bcl-2 in MCF-7 cells treated with conditioned-medium of $\mathrm{M} / \mathrm{si \alpha}$ or $0.5 \mathrm{ng} / \mathrm{ml}$ rhIFN- $\gamma$ was decreased, in contrast, that in MCF-7 treated with conditioned-medium of $\mathrm{M} / \mathrm{si} \beta$ or $0.5 \mathrm{ng} / \mathrm{ml} \mathrm{rhIL-4}$ was increased. These data suggest that autocrine IFN- $\gamma$ activity in breast cancer cells affects expression of ER $\beta$ and Bcl-2.

The pretreatment with IFN- $\gamma$ increases the sensitivity to TAM in MCF-7. ER $\alpha$ is regarded as a good biomarker for predicting the efficiency of endocrine therapy of breast cancer. Previous data show ER $\beta$, in some cases such as ER $\alpha$-negative breast cancer, may be a better predictor to assess the effect of treatment. In the present study, as shown in Fig. 7A, we found knockdown of ER $\alpha$ in MCF-7 markedly enhanced the sensitivity to TAM (1,5 and $10 \mu \mathrm{M}$, compared with vehicle control, $\mathrm{P}<0.01)$; whereas, knockdown of ER $\beta$ inversely inhibited the sensitivity to TAM (10 $\mu \mathrm{M}$, compared with vehicle control, $\mathrm{P}<0.01)$. Further investigation showed that compared with MCF-7 (both express ER $\alpha$ and $\beta$ ) and M/ si $\alpha$ cells (express ER $\beta$ ), the sensitivity to TAM in M/si $\beta$ cells (express ER $\alpha$ ) significantly decreased. However, when we pretreated $\mathrm{M} / \mathrm{si} \beta$ cells with $0.5 \mathrm{ng} / \mathrm{ml} \mathrm{rhIFN}-\gamma$ (equivalent to autocrine level) or $100 \mathrm{ng} / \mathrm{ml} \mathrm{rhIFN}-\gamma$ (level based on MTT assay in Fig. 4A), the sensitivity to TAM was significantly restored (Fig. 7B). As shown in Fig. 7C, $0.5 \mathrm{ng} / \mathrm{ml}$ rhIFN- $\gamma$ promoted mRNA expression of ER $\beta$. These data suggest that autocrine IFN- $\gamma$ may upregulate the sensitivity to TAM of MCF-7 cells at least partially via enhancing the expression of $\mathrm{ER} \beta$, although we only detected this enhancement at mRNA level.

\section{Discussion}

A body of growing evidence shows that two distinct estrogen receptors (ERs), ER $\alpha$ and ER $\beta$, are critical in the progression and prediction efficacy of antiestrogen therapy of human 
breast cancer, and ER expression is a dynamic phenomenon and is regulated by numerous factors, including cytokines in tumor microenvironment. However, there are conflicting studies and it has been unclear whether there is correlation between cytokines, ER subtypes and malignant behavior of breast cancer cells. In the present study, MCF-7, which expresses both $\mathrm{ER} \alpha$ and $\mathrm{ER} \beta$, as a representative breast cancer cell line, was used. Our results indicated that ER $\beta$ inhibits the progression of breast cancer. Within tumor microenvironment, IFN- $\gamma$ and IL-4 may exert opposite effects on malignant behavior. Moreover, we found that correlation existed between expression of IFN- $\gamma$ and ER $\beta$. We also demonstrated that autocrine IFN- $\gamma$ activity in MCF-7 increases mRNA expression of ER $\beta$ and enhances the sensitivity to tamoxifen (TAM).

Estrogens, particularly E2, have pleiotropic effects on a wide variety of aspects through ERs, namely ER $\alpha$ and $\beta$. Since its discovery in 1996, ER $\beta$ and its role in breast cancer is still being explored. Most studies find ER $\alpha$ promotes progression of breast cancer, but ER $\beta$ inhibits tumor formation due to its negative modulation of ER $\alpha$ transcription. In contrast, Murphy et al (32) suggested overexpression of ER $\beta 1$ can increase proliferation, invasiveness and metastasis in a ER $\alpha$-negative breast cancer cell line (31-33). The causes for the above differences include the presence of multiple variant isoforms of $\operatorname{ER} \beta$, consideration on whether ER $\beta$ is expressed alone or is co-expressed with $\mathrm{ER} \alpha$ and methods of determining ER $\beta$ expression (34-38). In the present study, we used MCF-7 cells expressing both $\mathrm{ER} \alpha$ and $\beta$ as the parental subject stably tranfected with ER $\alpha$ siRNA or ER $\beta$ siRNA, and then analyzed the malignant behavior of MCF-7 transfectants. Antibodies used in western blotting recognized the full length form of ER $\alpha$ and $\beta$ (i.e. ER $\beta 1$ ) protein with 65 and $55 \mathrm{kD}$. Our studies suggested knockdown of ER $\beta$ in MCF-7 can promote cell proliferation by increasing $\mathrm{G} 1$ phase distribution and upregulation of mRNA levels of the apoptosis suppressor genes, enhance the anchorage-independent growth ability and increase adhesion. Autocrine production of IFN- $\gamma$ by MCF-7 transfectants was positively correlated with ER $\beta$, but negatively with ER $\alpha$. However, there was no correlation found between autocrine IL-4 and ER subtypes.

Previous studies have demonstrated cancer tissues and cancer cells are another important resources of cytokines in tumor microenvironment, besides tumor-infiltrating immune cells $(24-26,39)$. IL-4 and IFN- $\gamma$, particularly produced by tumor or tumoral cells, may re-educate cells in tumor niche to avoid host immunological surveillance. It has been reported that IL-4 acts as an autocrine growth factor in pancreatic cancer cells by promoting the activation of AKT-1, Stat 3 and MAPK (25). In human primary prostate, breast and bladder cancer cells, IL-4 induces upregulation of cFLIP and Bcl-xL, which confer resistance to death receptor- and chemotherapeutic drug-induced apoptosis (26). As for IFN- $\gamma$ and other Th1 cytokines (e.g. IL-12), it is reported that their production tends to be suppressed, which often results in an inactivation of Th1 activity (40). In the present study, we illustrated a certain level of rhIFN- $\gamma$ (i.e. 100 or $250 \mathrm{ng} / \mathrm{ml}$ ) or rhIL-4 (i.e. 10 or $25 \mathrm{ng} / \mathrm{ml}$ ) may significantly inhibit or promote breast cancer cell growth and metastasis in vitro, respectively.
Consistent with previous studies (29), we found correlation between IFN- $\gamma$ and IL-4 levels and ER expression. In the present study, we showed that $100 \mathrm{ng} / \mathrm{ml} \mathrm{rhIFN}-\gamma$ or $10 \mathrm{ng} /$ $\mathrm{ml}$ rhIL-4 have direct positive or negative effect on protein expression of ER $\beta$, but not on ER $\alpha$ expression.

In contrast, we noticed the autocrine production of IFN- $\gamma$ and IL-4, not only in breast cancer cell lines MCF-7 and MDA-MB-231 but also in MCF-7 transfectants, was below $1 \mathrm{ng} / \mathrm{ml}$ level. Accordingly, it was doubted whether autocrine IFN- $\gamma$ or IL-4, including conditioned medium from MCF-7 transfectants with different ER subtypes expression and $0.5 \mathrm{ng} / \mathrm{ml}$ rhIFN- $\gamma$ or rhIL-4 (equivalent to autocrine level), would affect ER expression in MCF-7. We found autocrine IFN- $\gamma$ markedly upregulated ER $\beta$ mRNA expression, but did not affect $E R \beta$ protein expression, which may be due to the insensitivity of antibodies recognizing ER in western blotting. Our findings indicated that there may be a cycle in which IFN $-\gamma$ promotion by knockdown of ER $\alpha$ (i.e. relative overexpression of ER $\beta$ ) in MCF-7 would augment the level of ER $\beta$ further and vice versa. Moreover, we also noted the apoptosis suppressor gene Bcl-2 was decreased by treatment with conditioned medium from $\mathrm{M} / \mathrm{si} \alpha$ or $0.5 \mathrm{ng} / \mathrm{ml} \mathrm{IFN}-\gamma$, which indicated the possible inhibition on cell proliferation by autocrine IFN- $\gamma$.

As some previous studies show, ER $\alpha$ is regarded as a good biomarker to assess the efficiency of endocrine therapy in breast cancer for a long time. For this reason, patients with ER $\alpha$-positive tumors are treated with TAM, which blocks the action of ER $\alpha$ or with aromatase inhibitors, which block the synthesis of E2 $(41,42)$. However, ER $\alpha$ seems not to act as a predictor role invariably during the progression of breast cancer $(13,43,44)$. Recently, data support ER $\beta$ may be a better predictor of TAM effect than ER $\alpha$ in invasive breast cancers, which usually experience reduced expression of ER $\alpha$ (45-48). Consistent with the above studies, our results showed that knockdown of $E R \alpha$, i.e. relative overexpression of $E R \beta$ in MCF-7, markedly enhanced the sensitivity to TAM, whereas knockdown of $\operatorname{ER} \beta$, i.e. relative overexpression of $\mathrm{ER} \alpha$, inhibited TAM sensitivity. These findings indicated that ER $\beta$ maybe a good predictor for endocrine therapy in the cases of reduced expression of ER $\alpha$ during the advanced stage of breast cancer. Compared with MCF-7 (both express ER $\alpha$ and $E R \beta$ ) and $M /$ si $\alpha$ cells (express $E R \beta$ ), the sensitivity to TAM in $\mathrm{M} / \mathrm{si} \beta$ cells (express ER $\alpha$ ) significantly decreased. However, when we pretreated $\mathrm{M} / \mathrm{si} \beta$ cells with $0.5 \mathrm{ng} / \mathrm{ml}$ rhIFN- $\gamma$ (equivalent to autocrine level) or $100 \mathrm{ng} / \mathrm{ml} \mathrm{rhIFN}-\gamma$ (chosen level by MTT assay in Fig. 4A), the sensitivity to TAM of these cells was significantly restored. These data indicated that IFN- $\gamma$, including autocrine level, could restore the sensitivity to TAM of $\mathrm{M} / \mathrm{si} \beta$ cells, at least, partially via enhancing the expression of $\operatorname{ER} \beta$, although we only detected this enhancement at mRNA level.

In conclusion, our findings provided evidence of correlation between autocrine IFN- $\gamma$ and ER $\beta$ in malignant transformation and endocrine therapeutic prognosis. Furthermore, as the IFN- $\gamma$ exerted promotive activity on expression of $E R \beta$ and $E R \beta$ is a protective factor to the progression of breast cancer, we could deduce the combined treatment with IFN- $\gamma$ and TAM may provide a potentially benificial strategy in endocrine therapy of breast cancer. 


\section{Acknowledgements}

This study was supported by grants from the Tianjin Municipal Science and Technology Commission (no. 15JCYBJC26000).

\section{References}

1. Torre LA, Bray F, Siegel RL, Ferlay J, Lortet-Tieulent J and Jemal A: Global cancer statistics, 2012. CA Cancer J Clin 65: 87-108, 2015

2. Ziegler RG, Anderson WF and Gail MH: Increasing breast cancer incidence in China: The numbers add up. J Natl Cancer Inst 100: 1339-1341, 2008.

3. Yue W, Yager JD, Wang JP, Jupe ER and Santen RJ: Estrogen receptor-dependent and independent mechanisms of breast cancer carcinogenesis. Steroids 78: 161-170, 2013.

4. Mosselman S, Polman J and Dijkema R: ER beta: Identification and characterization of a novel human estrogen receptor. FEBS Lett 392: 49-53, 1996.

5. Williams $\mathrm{C}$ and Lin CY: Oestrogen receptors in breast cancer: Basic mechanisms and clinical implications. E Cancer Med Sci 7: 370,2013

6. Skliris GP, Munot K, Bell SM, Carder PJ, Lane S, Horgan K, Lansdown MR, Parkes AT, Hanby AM, Markham AF, et al: Reduced expression of oestrogen receptor beta in invasive breast cancer and its re-expression using DNA methyl transferase inhibitors in a cell line model. J Pathol 201: 213-220, 2003.

7. Han SJ, Guo QQ, Wang T, Wang YX, Zhang YX, Liu F, Luo YX, Zhang J, Wang YL, Yan YX, et al: Prognostic significance of interactions between ER alpha and ER beta and lymph node status in breast cancer cases. Asian Pac J Cancer Prev 14 6081-6084, 2013.

8. Platet N, Cathiard AM, Gleizes M and Garcia M: Estrogens and their receptors in breast cancer progression: A dual role in cancer proliferation and invasion. Crit Rev Oncol Hematol 51: 55-67, 2004.

9. Pettersson K, Delaunay F and Gustafsson JA: Estrogen receptor beta acts as a dominant regulator of estrogen signaling. Oncogene 19: 4970-4978, 2000.

10. Nilsson S, Mäkelä S, Treuter E, Tujague M, Thomsen J Andersson G, Enmark E, Pettersson K, Warner M and Gustafsson JA: Mechanisms of estrogen action. Physiol Rev 81: $1535-1565,2001$

11. Fuqua SA, Schiff R, Parra I, Moore JT, Mohsin SK, Osborne CK, Clark GM and Allred DC: Estrogen receptor beta protein in human breast cancer: Correlation with clinical tumor parameters. Cancer Res 63: 2434-2439, 2003.

12. O'Neill PA, Davies MP, Shaaban AM, Innes H, Torevell A, Sibson DR and Foster CS: Wild-type oestrogen receptor beta (ERbeta1) mRNA and protein expression in Tamoxifen-treated post-menopausal breast cancers. Br J Cancer 91: 1694-1702, 2004.

13. Kerdivel G, Flouriot G and Pakdel F: Modulation of estrogen receptor alpha activity and expression during breast cancer progression. Vitam Horm 93: 135-160, 2013.

14. Stassi G, Todaro M, Zerilli M, Ricci-Vitiani L, Di Liberto D, Patti M, Florena A, Di Gaudio F, Di Gesù G and De Maria R: Thyroid cancer resistance to chemotherapeutic drugs via autocrine production of interleukin- 4 and interleukin-10. Cancer Res 63: 6784-6790, 2003.

15. Mahmoud SM, Paish EC, Powe DG, Macmillan RD, Grainge MJ Lee AH, Ellis IO and Green AR: Tumor-infiltrating CD8 ${ }^{+}$ lymphocytes predict clinical outcome in breast cancer. J Clin Oncol 29: 1949-1955, 2011.

16. Nagai $\mathrm{S}$ and Toi M: Interleukin- 4 and breast cancer. Breast Cancer 7: 181-186, 2000.

17. Kmieciak M, Payne KK, Idowu MO, Grimes MM, Graham L, Ascierto ML, Wang E, Wang XY, Bear HD and Manjili MH: Tumor escape and progression of HER-2/neu negative breast cancer under immune pressure. J Transl Med 9: 35, 2011

18. Chen C, Guo L, Shi M, Hu M, Hu M, Yu M, Wang T, Song L, Shen B, Qian L, et al: Modulation of IFN- $\gamma$ receptor 1 expression by AP- $2 \alpha$ influences IFN- $\gamma$ sensitivity of cancer cells. Am J Pathol 180: 661-671, 2012.

19. García-Tuñón I, Ricote M, Ruiz A A, Fraile B, Paniagua R and Royuela M: Influence of IFN-gamma and its receptors in human breast cancer. BMC Cancer 7: 158, 2007.
20. Obiri NI, Siegel JP, Varricchio F and Puri RK: Expression of high-affinity IL-4 receptors on human melanoma, ovarian and breast carcinoma cells. Clin Exp Immunol 95: 148-155, 1994.

21. Obiri NI, Hillman GG, Haas GP, Sud S and Puri RK: Expression of high affinity interleukin-4 receptors on human renal cell carcinoma cells and inhibition of tumor cell growth in vitro by interleukin-4. J Clin Invest 91: 88-93, 1993.

22. Varricchio F, Obiri NI, Haas GP and Puri RK: Immunostaining of interleukin-4 receptor on human renal cell carcinoma. Lymphokine Cytokine Res 12: 465-469, 1993.

23. Toi M, Bicknell R and Harris AL: Inhibition of colon and breast carcinoma cell growth by interleukin-4. Cancer Res 52: 275-279, 1992.

24. Todaro M, Lombardo Y, Francipane MG, Alea MP, Cammareri P, Iovino F, Di Stefano AB, Di Bernardo C, Agrusa A, Condorelli G, et al: Apoptosis resistance in epithelial tumors is mediated by tumor-cell-derived interleukin-4. Cell Death Differ 15: 762-772, 2008.

25. Prokopchuk O, Liu Y, Henne-Bruns D and Kornmann M: Interleukin-4 enhances proliferation of human pancreatic cancer cells: Evidence for autocrine and paracrine actions. Br J Cancer 92: 921-928, 2005.

26. Conticello C, Pedini F, Zeuner A, Patti M, Zerilli M, Stassi G, Messina A, Peschle C and De Maria R: IL-4 protects tumor cells from anti-CD95 and chemotherapeutic agents via up-regulation of antiapoptotic proteins. J Immunol 172: 5467-5477, 2004.

27. Todaro M, Zerilli M, Ricci-Vitiani L, Bini M, Perez Alea M, Maria Florena A, Miceli L, Condorelli G, Bonventre S, Di Gesù G, et al: Autocrine production of interleukin-4 and interleukin-10 is required for survival and growth of thyroid cancer cells. Cancer Res 66: 1491-1499, 2006.

28. Turgeon C, Gingras S, Carrière MC, Blais Y, Labrie F and Simard J: Regulation of sex steroid formation by interleukin-4 and interleukin- 6 in breast cancer cells. J Steroid Biochem Mol Biol 65: 151-162, 1998.

29. Hong CC, Yao S, McCann SE, Dolnick RY, Wallace PK, Gong Z, Quan L, Lee KP, Evans SS, Repasky EA, et al: Pretreatment levels of circulating Th1 and Th2 cytokines, and their ratios, are associated with ER-negative and triple negative breast cancers. Breast Cancer Res Treat 139: 477-488, 2013.

30. Li HZ, Wang Y, Gao Y, Shao J, Zhao XL, Deng WM, Liu YX, Yang J and Yao Z: Effects of raf kinase inhibitor protein expression on metastasis and progression of human epithelial ovarian cancer. Mol Cancer Res 6: 917-928, 2008.

31. Huang B, Omoto Y, Iwase H, Yamashita H, Toyama T, Coombes RC, Filipovic A, Warner $M$ and Gustafsson JÅ: Differential expression of estrogen receptor $\alpha, \beta 1$, and $\beta 2$ in lobular and ductal breast cancer. Proc Natl Acad Sci USA 111: 1933-1938, 2014

32. Murphy LC and Leygue E: The role of estrogen receptor- $\beta$ in breast cancer. Semin Reprod Med 30: 5-13, 2012.

33. Tonetti DA, Rubenstein R, DeLeon M, Zhao H, Pappas SG, Bentrem DJ, Chen B, Constantinou A and Craig Jordan V: Stable transfection of an estrogen receptor beta cDNA isoform into MDA-MB-231 breast cancer cells. J Steroid Biochem Mol Biol 87: 47-55, 2003.

34. Hou YF, Yuan ST, Li HC, Wu J, Lu JS, Liu G, Lu LJ, Shen ZZ, Ding J and Shao ZM: ERbeta exerts multiple stimulative effects on human breast carcinoma cells. Oncogene 23: 5799-5806, 2004.

35. Fox EM, Davis RJ and Shupnik MA: ERbeta in breast cancer onlooker, passive player, or active protector? Steroids 73: 1039-1051, 2008.

36. Skliris GP, Leygue E, Curtis-Snell L, Watson PH and Murphy LC: Expression of oestrogen receptor-beta in oestrogen receptor-alpha negative human breast tumours. Br J Cancer 95: 616-626, 2006.

37. Monroe DG, Secreto FJ, Subramaniam M, Getz BJ, Khosla S and Spelsberg TC: Estrogen receptor alpha and beta heterodimers exert unique effects on estrogen- and tamoxifen-dependent gene expression in human U2OS osteosarcoma cells. Mol Endocrinol 19: 1555-1568, 2005.

38. Weitsman GE, Skliris G, Ung K, Peng B, Younes M, Watson PH and Murphy LC: Assessment of multiple different estrogen receptor-beta antibodies for their ability to immunoprecipitate under chromatin immunoprecipitation conditions. Breast Cancer Res Treat 100: 23-31, 2006

39. Jonsson P, Katchy A and Williams C: Support of a bi-faceted role of estrogen receptor $\beta(E R \beta)$ in ER $\alpha$-positive breast cancer cells. Endocr Relat Cancer 21: 143-160, 2014. 
40. Chavey C, Bibeau F, Gourgou-Bourgade S, Burlinchon S, Boissière $\mathrm{F}$, Laune $\mathrm{D}$, Roques $\mathrm{S}$ and Lazennec G: Oestrogen receptor negative breast cancers exhibit high cytokine content. Breast Cancer Res 9: R15, 2007.

41. Kidd P: Th1/Th2 balance: The hypothesis, its limitations, and implications for health and disease. Altern Med Rev 8: 223-246, 2003.

42. Hartman J, Lindberg K, Morani A, Inzunza J, Ström A and Gustafsson JA: Estrogen receptor beta inhibits angiogenesis and growth of T47D breast cancer xenografts. Cancer Res 66 : 11207-11213, 2006.

43. Brueggemeier RW, Hackett JC and Diaz-Cruz ES: Aromatase inhibitors in the treatment of breast cancer. Endocr Rev 26: 331-345, 2005.

44. Gutierrez MC, Detre S, Johnston S, Mohsin SK, Shou J, Allred DC, Schiff R, Osborne CK and Dowsett M: Molecular changes in tamoxifen-resistant breast cancer: Relationship between estrogen receptor, HER-2, and p38 mitogen-activated protein kinase. J Clin Oncol 23: 2469-2476, 2005.
45. Gallo D, De Stefano I, Grazia Prisco M, Scambia G and Ferrandina G: Estrogen receptor beta in cancer: An attractive target for therapy. Curr Pharm Des 18: 2734-2757, 2012.

46. Honma N, Horii R, Iwase T, Saji S, Younes M, Takubo K, Matsuura M, Ito Y, Akiyama $F$ and Sakamoto G: Clinical importance of estrogen receptor-beta evaluation in breast cancer patients treated with adjuvant tamoxifen therapy. J Clin Oncol 26: 3727-3734, 2008

47. Pitta CA, Papageorgis $\mathrm{P}$, Charalambous $\mathrm{C}$ and Constantinou AI: Reversal of ER- $\beta$ silencing by chromatin modifying agents overrides acquired tamoxifen resistance. Cancer Lett 337: 167-176, 2013.

48. Razandi M, Pedram A, Jordan VC, Fuqua S and Levin ER: Tamoxifen regulates cell fate through mitochondrial estrogen receptor beta in breast cancer. Oncogene 32: 3274-3285, 2013. 